\title{
ANALYSING THE STATE'S LAWS ON RELIGIOUS EDUCATION IN POST-NEW ORDER INDONESIA
}

\author{
Mohamad Yusuf*; Carl Sterkens ${ }^{* *}$ \\ *Corresponding Author, Gadjah Mada University Yogyakarta, Indonesia; \\ ${ }^{* *}$ Radboud University, Nijmegen, the Netherlands \\ email:yusuf.mohamad@gmail.com
}

\section{Abstract}

This article aims to analyse the Indonesian State's laws regarding models of religious education, by evaluating Law No. 20/2003, concerning the national system of education and other related laws. Two questions are highlighted: What type of religious education is favoured by Indonesian state? Does the preference for a certain type of religious education reflect a specific vision of the state-religion relationship? Our data consisted of two sources: the State's law on national education system, Law No. 20/2003, and the minutes of the Indonesian parliament meeting approving the law. We found that Law No. 20/2003 expresses the preference of the government for a mono-religious model. Indonesia is categoreized as having preferred treatment for some religions or support for a particular religious tradition. This categorisation is confirmed by the results of our research findings indicated by the preferential treatment delivered by the State, and the State's legislation and regulations on religion. Tulisan ini menganalisis legislasi negara terhadap pendidikan agama dengan cara mengevaluasi UU No. 20/2003 tentang Sistem Pendidikan Nasional beserta perundang-undangan terkait lainnya. Dua pertanyaan berusaha untuk dijawab dalam tulisan ini, yaitu: Model pendidikan agama yang bagaimana yang menjadi preferensi negara? Apakah preferensi tersebut merefleksikan visi negara terhadap model relasi negara-agama tertentu? Tulisan ini merujuk kepada dua data utama, yaitu: UU No. 20/2003 tentang Sistem Pendidikan Nasional serta Risalah Rapat Paripurna ke-35 DPR RI tabun 2003 yang mengesabkan UU No. 20/2003. Penelitian ini menemukan bahwa UU Sistem Pendidikan Nasional merefleksikan preferensi negara terhadap 
model pendidikan agama mono-relijus. Model pendidikan mono-religius ini merefleksikan preferensi negara terhadap model relasi negara-agama preferensial; negara mengakui lebih dari satu agama resmi dan memberi dukungan kepada institusi-institusinya, yang direfleksikan melalui legislasi dan peraturan terkait agama.]

Keywords: models of religious education, models of State-religion relationship, laws analysis

\section{A. Introduction}

Indonesian Parliament's approval on 20 June 2003 of Law No. $20 / 2003$ concerning the national education system has raised many questions, specifically with regard to the aim of national education and articles regulating religious education. Public debates responding to the draft on the national education system have been reported by local and national mass media during the three months prior to the approval of the bill by the parliament. The public responded to the draft of the bill by heated public debate in electronic media and newspapers; but also through demonstrations, both in favour of and against the draft. This law is a crucial document for understanding the State's preference for a certain type of religious education.

Discussions prior to the approval of the bill shed some light on the power relations between so-called Islamic groups and secular groups (together with non-Muslim groups). Even though a power struggle has existed since the early period of Indonesian independence in 1945, it became manifest in the discussions around the bill. Some researchers have indicated that Law No. 20/2003 merely expresses the interest of the religious majority group in having their model of religious education acknowledged by the State, and their education institutions accommodated in order to gain more State support. ${ }^{1}$

Considering the importance of Law No. 20/2003, there has not been much research analysing this legislation on education. Ichwan wrote his dissertation on the New Order and post-New Order politics of

${ }^{1}$ Moch. Nur Ichwan, "Official Reform of Islam: State Islam and the Ministry of Religious Affairs in Contemporary Indonesia, 1966-2004”, Ph.D. Dissertation (Tilburg: Universiteit van Tilburg, 2006); Robert W. Hefner (ed.), Remaking Muslim Politics: Pluralism, Contestation, Democratization (Princeton: Princeton University Press, 2005); Abd. Rachman Assegaf, Politik Pendidikan Nasional: Pergeseran Kebijakan Pendidikan Agama Islam dari Praproklamasi ke Reformasi (Yogyakarta: Kurnia Kalam, 2005). 
Islam and its impacts on the reform of Islamic affairs, especially those developed by the Ministry of Religious Affairs from 1966 to 2004. ${ }^{2}$ A part of his study investigates the official reform of Islamic education, and the shifting paradigm of national education, from a secular to a more religious character. Other research on religious education after the New Order administration was conducted by Permani, ${ }^{3}$ who studied the influence of Law No. 20/2003 on the economic aspects of Islamic schools in Indonesia. According to Permani, Law No. 20/2003 gives Islamic schools (such as madrasah) and some Islamic community learning centres (such as the majelis taklim) political recognition; and as a result of this, they receive more financial support from the government. None of these studies has analysed Law No. 20/2003 from a pedagogical perspective. What type of religious education has been favoured by the post-New Order regime after 1998? Which power influences the State in favour of a certain type of religious education?

This paper will analyse the preference of the Indonesian government for a specific type of religious education, by evaluating Law No. 20/2003 and related State laws. Moreover, we critically reflect on the preference for a specific type of religious education from the perspective of the relationship of the State to religious communities from 1998 onwards.

\section{B. State-Religion Relationship}

We adopt a typology for the State-religion relationship introduced by Jonathan Fox, which measures the role of government's involvement in religion. This typology has a strong empirical basis. It is based on Fox's analysis of the Religion and State data set, which is the result of a worldwide survey between 1990 and 2002, involving 175 countries. ${ }^{4}$

Fox distinguishes between two core possibilities, namely separation of state and religion, and state involvement in religion. ${ }^{5}$ Separation of State and religion is the absence of any State support for any religion, as well as the absence of any State restrictions on

\footnotetext{
${ }^{2}$ Ichwan, "Official Reform of Islam".

${ }^{3}$ Risti Permani, "The Economics of Islamic Education: Evidence from Indonesia", Ph.D. Dissertation (Australia: University of Adelaide, School of Economics, 2010).

${ }^{4}$ Jonathan Fox, A World Survey of Religion and the State (New York: Cambridge University Press, 2008).

${ }^{5}$ Ibid. 
religion or any regulation with regard to religion. State involvement in religion includes all four forms of actions of the State with regard to religion: support, restriction, legislation and regulation. Fox furthermore distinguishes between positive and negative involvement. In the case of positive State involvement, Fox postulates five models, ranging from the most positive to the least positive involvement in religion (models 1 to 5 below). In the case of negative State involvement, Fox postulates three models, ranging from the least negative to the most negative involvement in religion (models 6 to 8 below). We now present the eight models of State-religion relationship in greater detail, starting with five models of positive involvement. Fox specifically uses criterion 4 (religious regulation) to describe the negative involvement of the State in religion. However, in our study, regulations could also refer to a certain degree of positive State involvement.

\section{State with One Official Religion}

This model shows the most positive State involvement in religion, i.e. the most active support for a specific religion. The State identifies itself with one particular religion. Fox defines this model as a religious State model, where one religion is mandatory for all citizens; or as an absolute theocracy ${ }^{6}$. The State intensively endorses preferential treatment for the official religion, while members of non-State religions are restricted, prohibited from expressing their religious identity. The theocratic model has a high level of religious discrimination, and the State allows little room for dissenters. The State enforces religious education in public schools, and determines its aims, methods and curriculum content, to ensure that the practice of religious education is consistent with the State's vision of religion. The State establishes an official institution to deal with religious affairs, and to promote the 'true' religion. In this model, the State promulgates regulations to promote the official religion and to strengthen the role of official religion in public domains. Religious teachings, citizenship and society are blended, and indispensable to each other. $^{7}$

${ }^{6}$ Cole W. Durham Jr, "Perspectives on Religious Liberty: A Comparative Framework", in Religious Human Rights in Global Perspective: Legal Perspectives, ed. by Johan David Van der Vyver and John Witte (The Hague: Martinus Nijhoff Publishers, 1996), pp. 1-44.

${ }^{7}$ Fox, $A$ World Survey of Religion, p. 49. 


\section{State with more than One Official Religion}

In this model, the degree of positive involvement is slightly less than in the previous model, but the State still has a high positive involvement in religion. The State acknowledges more than one official religion and supports religious institutions. ${ }^{8}$ It applies preferential treatment to protect officially recognised religions, and to restrict membership of non-official religions. Religious discrimination towards official religions does not exist in this model, but may exist towards members of the nonofficial religions. Members of non-official religions may not be allowed to conduct their activities or promote their teachings and identities. The State enacts religious legislation through the establishment of a State institution, such as the Ministry of Religious Affairs. This institution aims to organise official religions, for instance by supervising religious practices and interaction between adherents of different religions.

The State produces religious regulations to protect religious freedom and grant religious activities. Religious freedom de facto means to take part in one of the official religions; and for the sake of religious harmony, people are not allowed to convert to another religion, even within the official religions. Religious conversion is perceived as an insult to religious commitment. Inter-religious communication is restricted, because it is perceived as causing a decrease in religious identity. People are encouraged to learn only their own religion, in order to strengthen their religious identity. The State supports religious education in public schools, and students are required to take a course on religious education at every study level. Religious education aims to strengthen commitment to one's own religion and to increase religious piety in the practice of one's own religion.

\section{Civil Religion Model}

The civil religion model refers to the situation in which one religion serves unofficially as the public's religion, although the State does not officially endorse a particular religion. The State acknowledges a specific religious tradition because it has played an important role in the country's history and culture. In this model, the State attempts to separate itself from religion, but remains positively engaged with religion. State regulations aim at equal protection and support of all religious groups. Therefore, negative State involvement and religious discrimination do not exist in this model. Also, unlike in the models mentioned previously,

${ }^{8}$ Ibid. 
the State does not produce legislation either to restrict religions or to organise and supervise the practice of and interaction between adherents from different religions.

\section{Cooperation Model}

In the cooperation model, the degree of separation between State and religion is greater than in the civil religion model, and the positive involvement of the State in religion is less intense. The State neither restricts members of religious minorities, nor discriminates against them - as in the civil religion model but unlike the civil religion model, in the cooperation model the State does not grant special status to a certain dominant religious tradition. Even though the State falls short of endorsing a particular religion, certain religions benefit from State support more than others. In this model, the larger religious denominations benefit more from State involvement, but the State does not specifically endorse any religious organisations, as it is committed to giving equal treatment to all religious groups. The State also does not produce religious legislation either to restrict certain religious groups or to oversee their religious activities. Through its regulations, the State may provide significant funding for religious activities, such as religious education in public schools, the maintenance of places of worship, and the subsidy of religious schools. ${ }^{9}$

\section{Supportive Model}

The supportive model has the weakest positive State involvement in religion compared to the previous models. In this model, the State might insist on separation of State and religion, but retain benevolent neutrality towards religion(s). The State might promote religions slightly, and support all religions more or less equally. This model can be seen as similar to the cooperation model, in the sense that the State accommodates religious symbols in public settings, provides religious holidays, etc.; and may recognise the importance of religion as a part of national or local culture. In this model, there is no negative involvement of the State through preferential treatment or religious discrimination.

The next three models all reflect negative involvement of the State in religion, ranging from the least negative involvement (model 6) to the highest level of negative involvement (model 8). These models also indicate that the more the State is negatively involved in religion, the less

${ }^{9}$ Ibid., p. 50. 
it separates itself from religion. In these models, the State uses religious legislation and regulations to treat religions negatively. ${ }^{10}$

\section{Separationist Model}

This model insists on rigid separation of State and religion; and to a certain degree, the State is apathetic towards religion. Any suggestion of State support for religion is considered inappropriate. ${ }^{11}$ Religious symbols are not allowed in public displays, and subsidies for religions through tax deductions are suspect. The State produces legislation and regulations to limit religious activities, but does not engage in religious discrimination or have a negative attitude towards all religion. In the separationist model, religious education is not permitted in public schools, but some teachings about religions from an objective point of view -such as history and phenomenology of religions-are permitted. Members of religious clergy are restricted from holding public office. In a more extreme form of separationist model, the State produces legislation on religion and makes strong attempts to limit religious activities in public life.

\section{Inadvertent Insensitivity Model}

In this model the State maintains separation from religion, and therefore preferential treatment, religious discrimination and religious legislation are not found in this model. With regard to the religious regulations, the State often fails to distinguish between the use of regulations in secular settings and their use in religious settings, for example in land-use planning, labour discrimination, etc. The State is inadvertent, in the sense that its regulations do not consider their implications for religious lives, and that they might be hostile towards religions. At this point, this model is in agreement with the next model, the hostility model, in which the State is hostile to religion.

\section{Hostility Model}

This model has the most negative State involvement in religion. According to this model, the State is hostile towards all religions, and sometimes even prosecutes them. Preferential treatment and religious discrimination do not exist in this model, as the State has a high negative involvement in all religions. The State produces legislation to control religion and to neutralise its influence in society. The State forbids

${ }^{10}$ Ibid., p. 49.

${ }^{11}$ Ibid., p. 48. 
religious activities and places of worship, and prevents religion from becoming a separate source of authority or basis for opposition. In the hostility model, the State enacts religious regulation to monitor and restraint religious activities. According to the State's regulation, all religious institutions should be registered, and must get State permission to conduct religious activities. Religious symbols and identity are banned in the public sphere. Any form of religious symbol or identity in public life is regarded as an offence to the State's authority.

\section{Types of Religious Education}

In the following discussion, we describe different types of religious education. We distinguish between mono-religious, multi-religious and inter-religious models of religious education based on the differences in cognitive, affective and attitudinal aspects in these models of religious education. $^{12}$

\section{Mono-religious Model}

Cognitively, the mono-religious model provides knowledge of and insight into one's own religion. This model leads to the construction of religious identity in accordance with one's own religious tradition. Through religious education, a person can grow deeper in faith and belong more strongly to a specific religious community. Dialogue may be conducted only for the purpose of conversion, rather than to promote mutual understanding. Affectively, the mono-religious model aims to increase a person's interest and involvement in a particular religion. Attitudinally, this model is meant to inculcate the motivation to participate in the religious practices of one's own religion. The mono-religious model only focuses on a particular religion. However, this does not necessarily imply complete disregard for other religions; they may be discussed from the perspective of one's own tradition, aiming to affirm one's own religious tradition (content). The mono-religious model is taught through internalisation of the beliefs, values and rituals of one's own religious tradition, without critical thinking (methods).

${ }^{12}$ Carl Sterkens, Interreligious Learning: The Problem of Interreligious Dialogue in Primary Education (Leiden: Brill Academic Publishers, 2001); C.A.M. Hermans, Participatory Learning: Religious Education in a Globalizing Society (Leiden: Brill Academic Publishers, 2003); Carl Sterkens and Mohamad Yusuf, "Preferences for Religious Education and Inter-Group Attitudes among Indonesian Students", Journal of Empirical Theology, vol. 28, no. 1 (2015), pp. 49-89. 


\section{Multi-religious Model}

The multi-religious model emphasises the need to deal with religious plurality. Cognitively, this model aims to introduce a person to many religions. Different religions are presented in terms of their own self-understanding. Affectively, this model aims to stimulate interest in studying different religions. Attitudinally, the multi-religious model tries to cultivate a respectful attitude towards people from different religions. The content of the multi-religious model consists of information about different religious traditions, presented in their own terms. Other religions are not viewed from the viewpoint of any other religion, because each religion is described according to its own terms (content). The multireligious model emphasises the accumulation of information about the beliefs, values and rituals of different religious traditions (methods).

\section{Inter-religious model}

The inter-religious model focuses on the dialogue between followers of different religions. This model seeks to express the uniqueness of each religious tradition, and at the same time to evaluate religious plurality in a positive way. Affectively, this model aims at effective communication between one's own religion and other religious traditions. Attitudinally, this model stimulates respect and willingness to engage in dialogue between religions. The inter-religious model is concerned with different religions from the point of view of a certain religion and other religions (content). The inter-religious model is taught through the internalisation of one's own religion, and the clarification of other religions through dialogue (methods).

\section{Preferred Type of Religious Education}

This section aims to answer the following question: 'What type of religious education is favoured by the State, as mentioned in Law No. 20/2003 and related regulations?" In order to answer this question, we analyse three aspects of above-mentioned law, namely: the aim of national education; the aim of religious education; and the curriculum content of religious education.

\section{Aim of National Education}

We refer to article 3 of Law No. 20/2003, which regulates the function and aim of national education. It stipulates that: 
National education functions to develop abilities, and to form dignified character and national civilisation in order to educate national life; (it) aims to develop the students' potentials so that they become persons imbued with human values who are faithful and pious to the one and only God ....

This article was initially split into two articles: the first (article 3) refers to the function of national education, while the second (article 4) explains the aim of national education. The last meeting of the Standing Committee of the House of Representatives, held before the plenary meeting, decided to conflate articles 3 and 4 into one. But the resulting article maintains the distinction between the function and the aim of national education. On one hand, the function of national education has secular characteristics, in the sense that it emphasises the relationship between citizen and State, and deals with the development of intellectual capacity. On the other, the aim of national education has religious characteristics. It relates to religious and spiritual development, and to the relationship between an individual person and God.

According to Law No. 20/2003, the aim of national education is to create a faithful and pious individual. The new article obliges educational processes to train students to be religiously faithful, to have strong religious commitment, and to be pious. The word for religious commitment (beriman) refers to a strong obligation to religion - belief in God and commitment to a certain religious denomination. The word for religious devotion (bertakwa) means obedience in one's involvement in the religious practices of one's own religion.

\section{Aim of Religious Education}

To analyse the aim of religious education, we refer particularly to article 30.2 and article 12.1 point (a) of Law No. 20/2003. The law has a special place for religious education not granted to other subjects. It defines its aim in great detail, as well as formulating its curriculum content. Article 30.2 of Law No. 20/2003 stipulates that: "Religious education has the function to prepare students to become community members who understand and practise religious values and/ or acquire expertise in bis or her own religion." According to this article, the aim of religious education focuses on two aspects: understanding and practising religion. By understanding religion, students are expected to become committed [beriman] to their own religion. 'Practising religion' refers to religious devotion [bertakwa]. This corresponds to the aim of national education described previously - 
to be committed to a certain religion [beriman] and to be devoted through the internalisation of religious values and practices [bertakwa]. How should religious education be implemented by students in order to achieve its stated aim, for them to have strong religious faith and to practise religion? Article 12.1.a stipulates that: "Every student in an educational unit deserves to receive religious education in accordance with his or her religion, imparted by an educator from a similar religious tradition." This states the rights of students, implying an obligation to be fulfilled by the school. However, these are not individual rights, but rather the rights of the community.

To further clarify Law No. 20/2003, especially with regard to the aim and implementation of religious education in schools, the government released Government Regulation [Peraturan Pemerintab] No. 55/2007 concerning religious education, enacted in October 2007. Article 1.2 stipulates that: 'Religious education is aimed at developing students' abilities in comprehending, embracing and practising religious values [...]" This article emphasises three important activities in the study of religion, namely to comprehend, to embrace and to practice religion. The word for 'to comprehend' (memahami) refers to the cognitive aspect of education. 'To embrace' (menghayati) is a typical Indonesian term implying the affective aspect of education. 'To practise' (mengamalkan) implies a continuous activity, referring to the attitudinal aspect. Article 1.2 is consistent with the aim of religious education stated in article 30.2 of Law No. 20/2003; religious education emphasises the development of religious understanding and encourages religious practices.

But Government Regulation No. 55/2007 presents another aspect to be included in the aim of religious education, namely 'to embrace' (menghayati), referring to the affective aspect of religious education. Government Regulation No. 55/2007 affirms article 12.1a of Law No. $20 / 2003$ with regard to the obligation of schools to provide students with religious education in their own religion, taught by a teacher from a similar religious tradition. Article 4.2 of Government Regulation No. 55/2007 mandates that: "Every student at every education unit deserves to receive religious education in accordance with his or her religion, imparted by a teacher from a similar religious background."

Another article indicating a preference for a mono-religious model is article 4.5 of Government Regulation No. 55/2007, which stipulates that "each education unit provides a space and opportunity for students to practise their own religious rituals." According to this article, students are entitled to practise religious rituals in schools; this is consistent with Al-Jāmi‘ah, Vol. 53, No. 1, 2015 M/1436 H 
the definition of the national education system stated in article 1.1 of Law No. 20/2003, that a school should become a learning environment which supports students in developing their potential for obtaining spiritual and religious strength through their own religion. Moreover, article 5.3 of Government Regulation No. 55/2007 mandates that:

Religious education encourages students to obey their religious teachings in daily life and utilise religion as the foundation of ethics and morality in their personal lives, families, society, and national life.

\section{Curriculum Content of Religious Education}

How should religious education be taught in the classroom? Which aspects are being considered in the course of religious education? Law No. 20/2003 addresses the main aspects to be included in the development of the curriculum content of national education. Article 36.3 of Law No. 20/2003 stipulates that:

The curriculum development is organized in line with the level of education within the framework of the Republic of Indonesia by taking into account [...] the enhancement of religious commitment and religious devotion.

This article confirms the other articles of Law No. 20/2003 concerned, with the inclusion of the phrases "to have strong religious commitment" and "to have religious devotion" as the main aspects to be included in the aim of the national education system, as well as in the aim of religious education in Indonesia.

Regulation No. 16/2010 of the Ministry of Religious Affairs gives guidance on the management of religious education in schools, to be consistent with Law No. 20/2003 and Government Regulation No. 55/2007. According to article 6 of MORA Regulation No. 16/2010,

The standard formulation of religious education content as mentioned by article 5 verse (1) means (a) to deepen and to widen the students' knowledge and religious insight; (b) to encourage students to practise their religious teachings in daily life; (c) to position religion as the foundation of noble character in personal life, family, society, and national life.

These articles (6a, b and c) clearly confirm the State's preference for a mono-religious model. Religious education should aim to develop knowledge of one's own religions (point a), to instil commitment to the religious rituals of one's own religion (point b), and to engage with the beliefs and values of one's own religion (point c). Referring to the 
indicators introduced in our previous discussion (section 2.3.2), point (a) refers to the cognitive aspect of the mono-religious model, while point (b) corresponds with the affective aim, and point (c) is compatible with the attitudinal aim.

\section{E. Religious Education in the Perspective of the State-Religion Relationship}

This section aims to investigate whether the State's preference for a mono-religious model reflects a specific view of the State-religion relationship. We refer particularly to the process in which Law No. $20 / 2003$ was approved in parliament. In our analysis we use the minutes of the parliamentary meeting dated 10 June 2003. We address two questions: (1) to what extend did Islamic and secular (together with nonIslamic) political factions influence the decisions made in the parliament meeting? (2) Which arguments did these two groups deliver to justify their support, particularly with regard to the inclusion of religious values and the school's obligation to provide religious education in line with each student's one's own religion?

\section{The Influence of Religious Communities on Policymaking}

The purpose of the plenary meeting on 10 June 2003 was mainly to hear the final statements and remarks from each political faction on the draft of the State's legislation on the national system of education. We will investigate the power relations between the Muslim and secular (and non-Muslim) groups as demonstrated at that meeting.

The minutes show that the plenary meeting was attended by two ministers (the Minister of Education and Culture, and the Coordinative Minister for General Welfare), who represented the government, and 287 out of 498 members of parliament -57.6 per cent of all members. All political factions were meant to have an opportunity to deliver their final statement and remarks on the draft for the national education system legislation. However, all members of the PDI-P (a secular party) abstained.

Even though the PDI-P party was the only political faction to abstain, the table indicates that some members from other political parties did join the meeting. This is because they dissented with the decision of their political party over the draft. But even though they were present at the meeting and delivered their refusal, it would not have helped to change 
the draft. For instance, Mr. Immanuel Ekadianus Blegur and Mr. Simon Patrice Morin from Golkar Party (Islam-friendly party), and Mr. Gregorius Seto Harianto from the National Awakening Party (Islamist party) were Christians who refused to participate in the plenary meeting, though their parties took part in the meeting to approve the draft. However, as the percentage of parliament members joining the meeting was over 51 per cent - the minimum number of participants to be able to hold the meeting- the meeting was executed.

Surprisingly, the meeting paid little attention to the content of the draft, which had some controversial articles. This was quite different from the situation outside the parliament building; mass demonstrations occurred in several parts of the country. Supporters and opponents of the draft had been clashing since March 2003 - three months before the plenary meeting. Why did the members of parliament not criticise the content of the draft? 'The answer is simply that almost all the members opposing the draft abstained from the meeting. The minutes indicate that Islamic values coloured the plenary meeting. Indeed, six out of nine political factions based their arguments for supporting the draft on Islamic texts: the Quran or Hadith. An example of the Quran cited, for instance, is 58:11 which says:

[...] and when ye are told to rise up, rise up; God will raise you up, to (suitable) ranks (and degrees), those of you who believe and who have been granted (mystic) Knowledge. And God is well-acquainted with all ye do.

This verse is quoted by the PPP and the PBB (both Islamist parties) to support the need for integration between the secular and the religious domains, as well as between knowledge enhancement and religious commitment (faith). Knowledge per se cannot stand alone, and should be based on religious commitment.

The other verse recited by this political faction is $5: 2$,

[...] help ye one another in righteousness and piety, but belp ye not one another in sin and rancour: fear God: for God is strict in punishment.

This verse is used to support the involvement of religious commitment and devotion in the articles of Law No. 20/2003. It shows the shift of the State's policy on national education, from the secular to the religious. This reflects the fact that Islamic political groups (both Islam-friendly and Islamist parties) are dominant in the decision of the parliament to approve the draft of the national system of education. They stress Islamic values to justify their political manoeuvring of the 
inclusion of the religious values into the draft of the national system of education.

\section{Statements of Political Factions Justifying the Draft}

With which arguments did the political fractions justify the draft, particularly with regard to the inclusion of religious values and the school's obligation to provide religious education based on one's own religion? According to the secular groups, the draft legislation would create religious favouritism and trigger communal tensions, as happened in 1997 to 2000. Their view was that the draft represented only the interests of the Muslim majority group. The minutes indicate that there was an informal meeting between the chairman and the leaders of each political faction following the plenary meeting to discuss two controversial issues: the article addressing the aim of national education (article 3), and the article that obliging schools to provide religious education for students appropriate to the religion of the students and taught by a teacher from a similar religious tradition (article 13). These were criticised not only by the non-Muslim groups (especially the Roman Catholics and Protestants), but also by the liberal progressive Muslim groups, as well as secular groups. The political parties who participated in the meeting -the majority of which were Muslim groups- agreed that those issues will not be discussed in the plenary, and that each political faction would support the draft legislation.

The next discussion presents the statements from each political faction. We will begin with the secular parties, followed by the Islamfriendly and Islamist parties.

The PDI-P won the 1999 general election, with 30.5 per cent of the total seats in parliament. This party is made up predominantly of secular and non-Muslim voters. All members of the PDI-P refused to attend the plenary meeting. One reason was that PDI-P disagreed with some articles in the draft, especially those related to the inclusion of religious values in the aim of national education, and to State intervention in the practice of religious education in private schools. In the refusal letter to the chairman of the plenary meeting - signed by Mr. Roy BB Janis and Mr. Tjahyo Kumolo (chairman and secretary of the PDI-P faction), the PDI-P insisted that parliament hold a major public discussion, in which scholars (i.e. academics, religious leaders, education activists) would be invited to discuss the draft in greater detail. In their press conference, as reported by the daily Kompas on 11 June 2003, Janis stated (referring to Al-Jämi'ah, Vol. 53, No. 1, 2015 M/1436 H 
article 1.1 of the draft legislation) that

this bill will not only cause polarisation between supporters and opponents, but is also very weak in the framework of law. Obviously, the bill is against the ideal objective of education, that is, to educate national life. The objective should not be to create pious individuals.

In this particular context, the PDI-P urged parliament to return to the neutral characteristics of the State's previous law, No. 2/1989, and demanded State impartiality to all religious communities.

The other secular party, the Indonesian United Nation Party [Partai Kesatuan Kebangsaan Indonesia, or KKI], initially refused to give their final speech responding to the draft. Some KKI members, for instance Mr. G. Seto Harianto, Mr. K. Tunggul Sirait and Mr. Arnold Nicolas Radjawane, sent letters of refusal to the chairman and wanted to withdraw from their responsibility as parliamentary members to take part in the decisionmaking. Eventually the party participated in the meeting, and delivered its position on the draft. Mr. Birinus Joseph Rahawadan, spokesperson of the KKI, pointed out that

[...] if most members of the parliament wish to approve it today [without any further public discussion], then we just want to say that we could not and do not want to obstruct it; but please allow us to respectively deliver a different opinion, dissenting with some articles in this bill.

The party argued that article 12.1. a has legalised State intervention, especially over the private and public spheres, in this case [over] the students' and the parents' [freedom]. Obviously, the State should not and does not need to intervene.

The Golkar Party was the second most popular party in parliament in terms of seats and the biggest of the Islam-friendly parties at that time. According to this party, the 1998 crisis in Indonesia was caused predominantly caused by the moral crisis. As pointed out by its spokesperson, Mr. H. Agusman St. Basa, the Golkar party stood for the need to rebuild the national character, among other things, through the involvement of religious values in State laws. The practice of education, especially of religious education, would help students to enhance religious commitment and practise religious rituals. He stated that:

[...] education itself is a process in which its ultimate objective is to mature the responsible citizens through educational processes. Obviously, [the objective of education] is not sufficient if only to develop the intelligence potentialities, it should also develop the potentialities in faith, piety, and 
noble character $[\ldots]$

He refers in his argument to the aim of national education, stated in article 30.3 of the Constitution amendment 2002, which emphasises the development of religious commitment and religious devotion in national education. From this statement, we might conclude that the Golkar party agrees on the inclusion of religious values in the aim of national education.

The opinions of the National Awakening Party [Partai Kebangkitan Bangsa, or PKB] on the inclusion of religious values and the obligation of schools to teach a mono-religious model are similar to the statements made by the Golkar party. According to the spokesperson of the PKB, Mr. K.H. Khalilurrahman, to have religious values in law is consistent with the spirit of the reformasi - that is, to put religion in a more central position in the public domains including in the national system of education. He stated:

Under the oppression of the totalitarian and authoritarian power in the past, we could understand the people's suspicion over the possibility of

State intervention in religious affairs in society through the law. However, it is impossible to think of such intervention nowadays when the curtain of reformation has widely opened, and in [a time characterised by] democratisation and human-rights enforcement.

This party relates democracy to two types of freedom: freedom from State intervention and freedom from the promotion of religious values in State laws. Obviously, this statement contradicts the section of the draft welcoming State intervention in the practice of religious education in private schools. According to this party, providing students with religious education about their own religion is consistent with human rights; that is, the right to learn in one's own religion and to practise one's own religious rituals. Most members of the PKB party have been educated in the pesantren tradition. It is therefore no surprise that the draft treats the madrasab and pesantren systems as on an equal footing with the public education system. This party encourages the State to support the Islamic education system so that they can develop better in the future.

The responses from the Islamist parties were rather similar to those of the Islam-friendly parties. The Islamist parties believe that intellectual capacity should be complemented by religious morality and spirituality as the primary aim of national education. The spokesperson of the PPP party, Mr. H. Muhammad Abduh Paddare, states that: "[...] 
meanwhile the implementation [of religious education] is particularly to increase religious commitment [keimanan], religious devotion [ketakwaan], and noble character [akblak, mulia] [...] "This party also considered that the article obliging schools to provide students with religious education in their own religion was the best way to manage the religious plurality of Indonesia. Paddare suggested that:

Regarding some articles which are problematic, especially those connected to the situation of being a plural nation, we believe that pluralism has been accommodated well in this bill, that is, by giving the right to every student to learn, explore and implement the religion that they believe in. This bill protects the freedom of religion, and forbids teaching of a certain religion to students which is different from their own religion.

According to this party, introducing students to the teachings of other religions would violate their religious freedom.

The minutes show that the Reformation faction is the most active faction in parliament, forcing parliament members to approve the draft without any changes. This party seems to have taken advantage of the absence from the meeting of the PDI-P members and some Christian members. The Reformation faction stated that article 13 of the draft represented the first and foremost pillar of the ideology of Pancasila, the belief in the one and only God, which is the opposite of the secular ideology. According to the spokesperson of this faction, Mr. Muhammadi, every person who disagrees with article 13 (the obligation to study only one's own religion) should be considered secular. As mentioned in section 1.3.2, secularism has a negative connotation in Indonesia, and secular persons are considered rebels.

The PBB party forced parliament to approve the draft legislation because it was consistent with and represented the national ideology of Pancasila and Constitution amendment 2002, particularly with regard to the need to include religious values. The spokesperson of the PBB, Mr. K.H. Nadjih Ahjat, said that:

The national education of Indonesia should pay attention not only to the domain of knowledge or the intellectual aspects, but also to the domain of religious commitment or faith [keimanan], religious devotion [ketakwaan] and the formation of noble character [akblak mulia]. Students should be able to deepen their own religious values in order to behave in accordance with those values.

With regard to the obligation of schools to provide religious 
education in accordance with the religion of their students, this party points out that: "One fundamental right for students is to receive religious education which is appropriate to their own religion, though they study in a school belonging to a different religion."

\section{F. An Ideal Type of Religious Education}

Law No. 20/2003 expresses the preference of the Indonesian government for a mono-religious model. Article 12.1 point (a) stipulates that every student must receive religious education in accordance with his or her own religion, imparted by an educator from a similar religious tradition. The preference for the mono-religious model is furthermore regulated by articles in a lower-ranking law - Government Regulation No. 55/2007. Article 4.5 of this regulation states that each education unit should provide a place for religious worship and an opportunity for students to practise their own religious rituals. Students must not only understand their own religion, but must also be able to practise the religious rituals of their own religion. Article 5.3 stipulates that religious education should encourage students to obey their religious teachings in daily life, and use religious values and norms as the basis of morality in their personal life, in society, and in national life.

According to article 6 of Ministry of Religious Education Regulation No. 16/2010, the formulation of the curriculum content for religious education should aim (a) to deepen and widen students' knowledge of and insight into their own religion, (b) to encourage students to practise their own religious teachings in daily life, (c) to position religion as the foundation of noble character in personal life, family, society, and national life. From our theoretical perspective, point (a) might refer to the cognitive aspect of religious education, while points (b) and (c) refer to the attitudinal aspect. The article seems to confirm our previous discussion that the State expects religious values to play a role in building the nation. Through religious education, students are expected to internalise values rooted in the teachings of their own religion, and implement them in their daily activities.

How do we understand these findings? The State's laws clearly indicate that Muslim students should only learn Islam, Christians should only study Christianity, and Hindu students should only study Hinduism. In other words, religious education should not provide an opportunity for students to learn about other religions, or to come to mutual 


\section{Mohamad Yusuf \& Carl Sterkens}

understanding or have dialogue with other religious believers. Article 12.1 point (a) of Law No. 20/2003 uses the word 'deserve', referring to the rights of students which need to be fulfilled by schools. However, in order to understand this correctly, we need to understand these are not the rights of individuals, but of communities. The State demands students who are committed to their community, and who hold and practise similar normative values to the community. Article 30.2 of Law No. 20/2003 states that through religious education, the State expects to prepare students to become community members who understand and practise the religious values of their own religion. This reflects the communitarian idea, stressing the importance of communal cohesion. A certain value is considered good because that value is embedded in the community. ${ }^{13}$ When students do not learn the religious education of their own religious community, this breaks the cohesion of the community.

The preference for the mono-religious model also reflects the underlying fear of some Muslim groups that Christian schools will convert Muslim students to Christianity. Steenbrink ${ }^{14}$ studied this in the city of Yogyakarta, where some 16,500 Muslim students of primary schools received Christian religious education. Most Christian schools provide only Christian religious education - for all students, regardless of their religious background. In his research about the threatened feeling among Indonesian Muslims, Mujiburrahman discovered that Muslim groups perceive Christian schools as a means for promoting Christian teachings and converting others to Christianity. According to Mujiburrahman, ${ }^{15}$ Muslim students at a Christian school who are given Christian religious education will face at least two potential problems: they may become sceptical of and uncommitted to Islamic teachings, and they may convert to Christianity.

\section{G. Concluding Remarks}

Fox categorises Indonesia post-New Order regime as having "preferred treatment for some religions or support for a particular

${ }^{13}$ Robert Alun Jones, Emile Durkheim: An Introduction to Four Major Works (Universitas Michigan: SAGE Publications, 1986).

${ }^{14}$ Karel Steenbrink, Catholics in Indonesia, 1808-1942: A Documented History. Volume 2: The Spectacular Growth of a Self Confident Minority, 1903-1942 (Leiden: KITLV Press, 2007).

${ }^{15}$ Mujiburrahman, Feeling Threatened: Muslim-Christian Relations in Indonesia's New Order (Leiden: Amsterdam University Press; ISIM, 2006), p. 243. 
religious tradition" ${ }^{16}$ His categorisation is confirmed by the results of our research findings (particularly with regard to the State-religion relationship in Indonesia), indicated by the preferential treatment delivered by the State, and the State's legislation and regulations on religion.

With regard to preferential treatment, the State adopts religious values from the Islamic tradition in its laws. Indeed, the involvement of religious values can be traced back to the Constitution as amended in 2002. The amendment stipulated that the national system of education should involve religious values. Since then, religious values have become an important aspect of laws dealing with education.

Obviously, the post-New Order era has seen a rejection of the religious political restrictions and repressive approach towards religious activities in the public sphere. ${ }^{17}$ The resignation of President Suharto in May 1998 presented an opportunity for religious political groups, including the Islamic groups, to enter national politics. In the first two general elections after the resignation of President Suharto, Islamic political parties gained significant votes. ${ }^{18}$ They achieved 34.2 per cent in the 1999 general election, increasing slightly to 38 per cent in the 2004 election. This is very significant compared to the achievements of the secular and Christian groups, who gained 34.7 per cent in 1999 but dropped to 19.5 per cent in 2004. As a consequence, Muslim involvement in State law-making is unavoidable. Hefner ${ }^{19}$ and others ${ }^{20}$ have observed that the growing role of Muslim power in law-making beginning in the

${ }^{16}$ Fox, $A$ World Survey of Religion, p. 202.

${ }^{17}$ Luthfi Assyaukanie, Islam and the Secular State in Indonesia (Institute of Southeast Asian Studies, 2009).

${ }^{18}$ Baswedan (2004) separates Indonesian political parties after the New Order regime into three categories: the Secular, the Islam-friendly and the Islamist parties. The first category contains two secular parties and one Christian party. The secular parties are the Indonesia Democracy-Struggle Party [Partai Demokrasi Indonesia-Perjuangan, or PDI-P] and the Indonesia National Unity Party [Partai Kesatuan Kebangsaan Indonesia, or PKKI], while the Christian party is the Love the Nation Democratic Party [Partai Demokrasi Kasih Bangsa, or PDKB]. The Islam-friendly parties are the Golkar Party and the National Awakening Party [Partai Kebangkitan Bangsa, or PKB]. Finally, there are four Islamist parties: the United Development Party [Partai Persatuan Pembangunan, or PPP], the Crescent and Star Party [Partai Bulan Bintang, or PBB], the Justice Party [Partai Keadilan, or PK], and the National Mandate Party [Partai Amanat Nasional, or PAN].

${ }^{19}$ Robert W. Hefner, Making Modern Muslims: the Politics of Islamic Education in Southeast Asia (Honolulu: Univ. of Hawaii Press, 2009).

${ }^{20}$ R. William Liddle, "Indonesia in 1999: Democracy Restored", Asian Survey, vol. 40, no. 1 (2000), pp. 32-40; Baswedan, "Political Islam in Indonesia”, pp. 669-90. Al-jämi'ah, Vol. 53, No. 1, 2015 M/1436 H 
last 10 years of President Suharto's administration was triggered by at least two connected events: first was the replacement of Christians with Muslims in the State's bureaucracy, which implies a new composition that would benefit Muslim groups in accessing the political decision-making processes. Second is that since the late 1980s, the Golkar party -the government political party- has accommodated Muslim intellectuals, such as the alumni of the Muslim Students Association (Himpunan Mahasiswa Islam, or HMI). According to Hefner, HMI alumni are currently found in all political parties, but the Golkar party is practically dominated and led by them.

With regard to education system, Law No. 20/2003 uses the words iman and takwa as the ultimate goal of the national educational system, and akblak, to describe moral behaviour. Iman is defined as the acknowledgement of God, with full sincerity of heart and accepting all His attributes and their obvious corollaries. Takwa translates to 'selfconsciousness of Allah'. It describes a state of awareness of Allah in everything people do, and letting that awareness guide their actions and shield them from harm. Akblak is defined as disposition, nature, temper, ethics, morals or manners based on Islamic values and norms. ${ }^{21}$

The preference for a mono-religious model existed in the previous law (No. 2/1989), but the current law (No. 20/2003) has strengthened that preference. The State obliges religiously affiliated schools to provide Islamic religious education for Muslim students if they admit Muslim students. Unlike the previous legislation (Law No. 2/1989, enacted during the New Order regime), Law No. 20/2003 is regarded as 'more Islamic'. It reflects the Islamisation of law, in the sense that it accommodates Muslim interests greatly, particularly with regard to the State's support of Islamic education systems such as madrasah and pesantren.

Preferential treatment is also evident in the regulations produced by the State's institutions. In 2010, the Ministry of Religious Affairs established the Directorate General of Islamic Education, which consists of four Directorates, namely the Directorate of Madrasah, the Directorate of Islamic Primary Schools and Islamic Boarding Schools [Pendidikan Diniyah dan Pondok Pesantren], the Directorate of Islamic Higher Education [Pendidikan Tinggi Islam], and the Directorate of Islamic Religious Education [Pendidikan Agama Islam]. These institutions organise the Islamic education system, such as the madrasah and the pesantren

${ }^{21}$ Caesar E. Farah, Islam: Beliefs and Observances, 7th edition (New York: Barron's Educational Series, 1968). 
(Islamic boarding schools) and formulate the national curriculum of Islamic education. In addition, the Ministry of Religious Affairs uses its budget to support Islamic education systems such as the madrasah. The students of the madrasab mostly come from a background of lower economic status.

We can also understand the mono-religious model as a social fact because it consists of norms and values that are practised by and commonly found in all members of society. In Indonesia, there is clear agreement with regard to the practice of religious education by the policy-making body of the State (politicians, government); the educational system of religiously-affiliated schools, for instance school leaders, teachers, ${ }^{22}$ and student ideas on religious education. ${ }^{23}$ Althoug there are some differences in the mono-religious model employed at some religiously-affiliated schools, notably where schools introduce students to the teachings of other religions using an outsider's perspective, or the school provides mono-religious education for students not belonging to the religion to which the school is affiliated. But these differences are within the same social order, or as Durkheim says, "within the narrow limit of variation". ${ }^{24}$ They all practise religious education in such a way that students (should) develop knowledge based on their own religion, be committed to their own religion, and should become pious and moral persons based on the teachings of their own religion.

The result is a challenge to the fact that Indonesia is a religiously pluralistic country. According to many scholars, the mono-religious model has at least two weaknesses: (1) with regard to the dynamic of religious interpretation, and (2) its recognition of religious plurality. ${ }^{25}$ First, with the mono-religious model there is no need to contextualise, because context does not add anything to the teaching of religion (e.g. rituals, stories,

${ }^{22}$ Mohamad Yusuf and Carl Sterkens, "Religious Education in Religiously Affiliated Schools and the Influence of the State and Religious Community on School Politics", in Muslim Christian Relations Observed: Comparative Studies from Indonesia and the Netherlands, ed. by Volker Küster, Robert Setio, and Indonesian Dutch Consortium on Muslim-Christian Relations (Leipzig: Evangelische Verlagsanstalt, 2014), pp. 47-71.

${ }^{23}$ Sterkens and Yusuf, "Preferences for Religious Education".

${ }^{24}$ Emile Durkheim, The Rules of Sociological Method, 8th edition, ed. by George E.G. Catlin, trans. by Sarah A. Solovay and John H. Mueller (New York: Free Press, 1965).

${ }^{25}$ Sterkens, Interreligious Learning, p. 52; Hans-Georg Ziebertz and Didier Pollefeyt, "A Move to Multi? Empirical Research Concerning the Attitudes of Youth towards Pluralism and Religion's Claims of Truth", in Interreligious Learning (Leuven Paris: Peeters Publishers and Booksellers, 2007), pp. 3-24. 
etc.). In some religious traditions, contextuality in religion is perceived as imperfection and deviation from the tradition of the mainstream. For instance, ideas of religious purification confirm the resistance of religious communities to new ideas and insights. This idea is reflected in the aim of the mono-religious model, where the identity of a new generation is perceived to be a repetition of what is considered to be the 'original' religious identity.

Second, with regard to the recognition of religious plurality, the mono-religious model does not provide students with the opportunity to learn about different religions and from other religious believers. Students are only able to enhance their knowledge of their own religion, while they pretend to live in a mono-religious situation which does not actually exist in our global society. ${ }^{26}$ Recognition of other religious traditions is a problem for the mono-religious model - it does not approach other religions in terms of their own self-understanding. Other religions are interpreted and evaluated entirely from an outsider's perspective, i.e. from the seeker's own frame of reference.

There is a danger that the mono-religious model could lead to ethnocentrism or religiocentrism. ${ }^{27}$ It runs the risk of strengthening positive in-group attitudes, and negative attitudes towards religious outgroups. As predicted by contact theory, a consequence of religiocentrism is that students trust only those who share their religious identity. It can cause people to refuse to have more than a minimum of social contact with persons from other religions, and to have a claim to absolute religious truth.

${ }^{26}$ Hans Küng, Global Responsibility: in Search of a New World Ethic (New York: Crossroad Pub. Co., 1991).

${ }^{27}$ Sterkens, Interreligious Learning, p. 53. 


\section{BIBLIOGRAPHY}

Assegaf, Abd. Rachman, Politik Pendidikan Nasional: Pergeseran Kebijakan

Pendidikan Agama Islam dari Praproklamasi ke Reformasi, Yogyakarta: Kurnia Kalam, 2005.

Assyaukanie, Luthfi, Islam and the Secular State in Indonesia, Institute of Southeast Asian Studies, 2009.

Baswedan, Anies Rasyid, "Political Islam in Indonesia: Present and Future Trajectory”, Asian Survey, vol. 44, no. 5, 2004, pp. 669-90 [http:// dx.doi.org/10.1525/as.2004.44.5.669].

Durham Jr, Cole W., "Perspectives on Religious Liberty: A Comparative Framework", in Religious Human Rights in Global Perspective: Legal Perspectives, ed. by Johan David Van der Vyver and John Witte, The Hague: Martinus Nijhoff Publishers, 1996.

Durkheim, Emile, The Rules of Sociological Method, 8th edition, ed. by George E.G. Catlin, trans. by Sarah A. Solovay and John H. Mueller, New York: Free Press, 1965.

Farah, Caesar E., Islam: Beliefs and Observances, 7th edition, New York: Barron's Educational Series, 1968.

Fox, Jonathan, A World Survey of Religion and the State, New York: Cambridge University Press, 2008.

Hefner, Robert W. (ed.), Remaking Muslim Politics: Pluralism, Contestation, Democratization, Princeton: Princeton University Press, 2005.

----, Making modern Muslims: the Politics of Islamic Education in Southeast Asia, Honolulu: Univ. of Hawaii Press, 2009.

Hermans, C.A.M., Participatory Learning: Religious Education in a Globalizing Society, Leiden: Brill Academic Publishers, 2003.

Ichwan, Moch Nur, "Official Reform of Islam: State Islam and the Ministry of Religious Affairs in Contemporary Indonesia, 19662004", Dissertation, Tilburg: Universiteit van Tilburg, 2006.

Jones, Robert Alun, Emile Durkheim: An Introduction to Four Major Works, Universitas Michigan: SAGE Publications, 1986.

Küng, Hans, Global Responsibility: in Search of a New World Etbic, New York: Crossroad Pub. Co., 1991.

Liddle, R. William, "Indonesia in 1999: Democracy Restored", Asian Survey, vol. 40, no. 1, 2000, pp. 32-42 [http://dx.doi.org/10.2307/3021218]. 
Mujiburrahman, Feeling Threatened: Muslim-Christian Relations in Indonesia's New Order, Leiden: Amsterdam University Press; ISIM, 2006.

Permani, Risti, "The Economics of Islamic Education: Evidence from Indonesia", Ph.D. Dissertation, Australia: University of Adelaide, School of Economics, 2010.

Steenbrink, Karel, Catholics in Indonesia, 1808-1942: A Documented History, Volume 2: The Spectacular Growth of a Self Confident Minority, 1903-1942, Leiden: KITLV Press, 2007.

Sterkens, Carl, Interreligious Learning: The Problem of Interreligious Dialogue in Primary Education, Leiden: Brill Academic Publishers, 2001.

Sterkens, Carl and Mohamad Yusuf, "Preferences for Religious Education and Inter-Group Attitudes among Indonesian Students", Journal of Empirical Theology, vol. 28, no. 1, 2015, pp. 49-89 [http://dx.doi. org/10.1163/15709256-12341324].

----, "Religious Education in Religiously Affiliated Schools and the Influence of the State and Religious Community on School Politics", in Muslim Christian Relations Observed: Comparative Studies from Indonesia and the Netherlands, ed. by Volker Küster, Robert Setio, and Indonesian Dutch Consortium on Muslim-Christian Relations, Leipzig: Evangelische Verlagsanstalt, 2014, pp. 47-71.

Ziebertz, Hans-Georg and Didier Pollefeyt, "A Move to Multi? Empirical Research Concerning the Attitudes of Youth towards Pluralism and Religion's Claims of Truth", in Interreligious Learning, Leuven Paris: Peeters Publishers and Booksellers, 2007. 